\title{
Insanity and Imprisonment in British Guiana, 1814-1966 ${ }^{1}$
}

\author{
Clare Anderson, ${ }^{2}$ Kellie Moss $^{3}$ and Estherine Adams ${ }^{4}$
}

\begin{abstract}
This paper explores links between incarceration and enslavement, migration, and mental health, in the colony of British Guiana. Contemporaries recognised the negative impact that mobility and labour had on the health and well-being of enslaved persons and Asian immigrants, including on plantations. Understandings of 'insanity' later developed to bring ideas about biology, context, and behaviour into dialogue, including through the racialisation of its prevalence and character amongst the colony's diverse population. Before the construction of separate institutions, people who were believed to be suffering from mental illness were sometimes kept in jails, and due to a lack of capacity this continued even after lunatic asylums were developed from the 1840s. At the same time, colonial administrators recognised that incarceration itself could cause mental ill-health, and as such into the early twentieth century British Guiana engaged with global debates about criminal insanity.
\end{abstract}

Keywords: History, Insanity, Mental Health, British Guiana, Guyana's Prison System, Incarceration, Criminal Insanity, Colonial Prison's, Enslavement, Migration

[W]e are goaded to madness;

every day almost we are shamefully treated;

we have borne it peaceably but we can bear it no longer

\section{Petition of Sidooal, Hurril, and Juggernaut, 1869}

(PP 1871 [393] Appendix G)

The British occupied Dutch Guiana intermittently at the turn of the nineteenth century, in 1803 finally taking control of a society of enslaved Africans in Demerara, Essequibo, and Berbice. Under the terms of the capitulation, the British respected the political, economic, and social status quo, including Roman-Dutch law. This continued when the British united Demerara and Essequibo in 1814, and then in 1831 merged them with the colony of Berbice to form British Guiana (The Annual Miscellany 1817; Glenn 2008, 56; Penson 1926, 111-12). The Dutch first introduced imprisonment to Guiana in the seventeenth century, building jails in the capital at Stabroek (renamed Georgetown in 1812), and the east coast town of New Amsterdam. Until the 1820 s, they were mainly used to confine enslaved men and women awaiting trial (PP 18267 [008]). During that decade, the colony passed amelioration laws, with the goal of improving conditions for enslaved plantation labour as a precursor to eventual abolition. These reduced

\footnotetext{
1 This paper is based on research conducted for the ESRC-funded project Mental Health, Neurological and Substance Abuse (MNS) Disorders in Guyana's Jails: 1825 to the present day (award no. ES/S000569/1). This project is a collaboration between the University of Guyana and the University of Leicester, in partnership with the Guyana Prison Service. The project brings into dialogue researchers in History, Criminology, Sociology and Literature. It takes both a multi-disciplinary and interdisciplinary approach to key questions about the form, function, and experience of incarceration, encompassing inmates and the people who work with them. It encompasses both the British colonial period, and the era since Guyana's independence in 1966.

${ }^{2}$ Professor of History, School of History, Politics and International Relations, University of Leicester, Leicester, UK. Email: ca26@1e.ac.uk. ORCID: 0000-0003-0679-887X.

${ }^{3}$ Research Associate, School of History, Politics and International Relations, University of Leicester, Leicester, UK. Email: km345@le.ac.uk. ORCID: 0000-0002-2194-3935.

${ }^{4}$ Lecturer, Department of Social Studies, University of Guyana, Guyana. Email: estherine.adams@uog.edu.gy.
} 
the right of slaveowners to punish their human chattel, notably through restricting flogging, yet in other ways guaranteed their property rights over them. Simultaneously, the British brought punishment under the purview of the state, increasing the use of other technologies of punishment, such as solitary confinement, stocks, and treadmills (Browne 2017, 52; PP 18267 [008]; TNA CO111/542/2; TNA CO111/67/31).

Slavery was abolished in 1834, and over the next four years the British built prisons in Wakenaan, Mahaica, and Capoey to manage ex-slaves then made to work as 'apprentices' to their former owners. Following the end of the apprenticeship system in 1838, the British constructed another institution in isolated Mazaruni. Here, Her Majesty's Penal Settlement (HMPS) blended features of imprisonment with the distant relocation associated with penal transportation (Anderson et al 2020). Guiana's jail-building programme was influenced by a global shift to new architectures of separate confinement in single cells, designed to encourage religious reflection, instruction, and occupational training as means of punishment, deterrence, and rehabilitation (Gibson 2011; Morris \& Rothman 1998). However, in the British colonial context it was also driven by the desire to manage and control populations and harness their labour for public works and private industry (Arnold 1994; Browne 2017; Paton 2004). In Britain, the state gradually withdrew prisoners from such outdoor labour, but this was not the case in Guiana where, as in other colonies, the colonial administration continued to exploit them as workers. In this regard, prisons were part of a larger repertoire of colonial governance which also included laws to control mobility, collective gatherings, and labour strikes (Rodney 1981; TNA CO113/1/16; TNA CO113/1/23; TNA CO113/1/30).

After emancipation, the British parliament awarded slaveowners compensation for the loss of their property; the formerly enslaved got nothing. Following the recruitment of a small number of immigrants from the British Isles, Germany, and Madeira in the 1830s, planters in Guiana used this money to invest in indentured labour, mainly imported from India (Burnard \& Candlin 2019; Hall et al 2014). The state bound these immigrants to plantations through laws that restricted their right to change employers, negotiate for better wages, and move freely around the colony (Roopnarine 2014, 159; TNA CO113/2/20). The combination of emancipation and indenture underpinned a significant expansion in the number of prisons in British Guiana, and a sharp increase in rates of incarceration. In 1834, 1.9 per cent of the population was in prison; by 1862 this reached a colonial era peak of 2.9 per cent. By 1885 the colony imprisoned more than three times as many people as England and Wales: 1.97 per cent of the population compared to 0.64 per cent (Anderson et al 2020; Kirke 1888, 3). Existing institutions became so overcrowded that the colony opened or re-opened district prisons specifically for indentured immigrants who had breached labour laws, in Fellowship (1868), Mahaica (1868), and Suddie (1875). Finally, with the opening up of mines in the 1920s and 30s, government set up new prisons in Annai, Kamakusa, Mabaruma, and Kurupukari to manage gold prospectors (Moss et al 2019).

There are important connections to be made between enslavement, migration, and mental health. The abysmal conditions experienced by African captives during the middle passage weakened bodies and minds and caused immense distress and trauma which were manifested in sickness, hunger strikes, and suicide. Indentured migrants also endured long journeys, during which they were confronted with poor conditions and unfamiliar cultural practices, including for Hindus caste transgressions invoked by crossing the kala pani, or black waters (Gramaglia 2013, 66-7; Mustakeem 2015; Smith 2014, 30-1, 134n36). Neither were enslavement and indenture in the colony conducive to good mental health. Enslaved and indentured workers were often separated from family and isolated from community support 
and subjected to poor conditions on the plantations (Gramaglia 2013, 62-3, 66; Smith 2014, 22). For the African-Guyanese population, emancipation was a challenge, as economic options narrowed, employers had a preference for their new coerced labour force, structural change in agriculture impacted negatively, and there was a depression in trade. The formerly enslaved became impoverished, migrating to increasingly overcrowded urban areas or leaving the colony altogether (Smith 2014, 22). In regard to indentured immigration, by the end of the nineteenth century, colonial surgeons recognised that in some cases it caused poor mental health, but they also racialised it by making links between biology, context, and behaviour (Gramaglia 2013, 62-3; Grieve 1880, 130-4; Smith 2014, 22). Rates of admissions to the asylum were generally lower than those in Britain. As ideas of social Darwinism and then biological determinism garnered favour during the nineteenth century, by the 1880 s surgeons were expressing the view that this was because colonized peoples were less 'developed' than Europeans (Law 1888, 29). At the same time, there were claims that Indian immigrants suffered 'mental depression' after their hopes for a better life in the colony were not realised (Law 1888, 25). This was part of a larger discourse of racialisation, which sought to explain the prevalence and character of insanity among the colony's cosmopolitan population (Donald 1876; Grieve 1880; Grieve 2010; Gramaglia 2013).

There are also linkages between colonialism, mental health and incarceration. Prior to the construction of a lunatic asylum in Georgetown in 1842 the British used jails to confine those displaying signs of mental illness, though we lack precise descriptions of these manifestations. For example, the 'insane' 52-year-old man Addison was kept in Berbice Gaol from 1819-1831, despite being described as 'perfectly harmless'. Similarly, in 184122 individuals, also certified as 'insane', were confined in Georgetown prison. They included 55year-old James who had been there since 1829 (TNA CO116/176-81; TNA CO116/208-11). This practice, commonly utilised throughout the British Caribbean, reflected the authorities' perceived linkage between mental illness and criminality (Smith 2014, 35). For the confined this meant a regime based on custody and punishment, including the use of restraints. For instance, in New Amsterdam prison in 1831 the 'insane' free woman Felicia was confined in the stocks due to 'outrageous behaviour'. She remained in the prison until 1849 (TNA CO116/178; TNA CO116/218). Sometimes, attempts were made to isolate those with poor mental health from inmates, but in practice there was often little difference in the conditions they experienced, and like prisoners, they found themselves kept in cells with limited means of occupation, employment or exercise. The completion of the colony's new lunatic asylum in New Amsterdam in 1867 brought some relief, but there remained limitations of space (TNA CO116/213). Indeed, Felicia's experience was not unique and in the years that followed prisons continued to be used as overflow facilities (TNA CO116/213-222). As a result, many jails retained separate facilities, including in the third quarter of the nineteenth century a padded cell at HMPS Mazaruni (PP 1875 [1338]b).

The introduction of an 1846 ordinance for the 'safe custody of insane persons charged with offences' placed additional emphasis on the state to incarcerate indefinitely those with mental health problems (TNA CO113/1/25). This law embodied the contemporary mental health legislation of England and Wales, authorising also preventative detention through the imprisonment of 'dangerous persons suspected of being insane'. This codified earlier representations of criminal offending and mental illness, blurring substantially the distinctions between them (UK Acts of Parliament 1 \& 2 Vict., c. 14 Criminal Lunatics Act 1838; 3 \& 4 Vict., c. 54 Criminal Lunatics Act, 1840; 8 \& 9 Vict., c. 100 Lunatics Act 1845). It meant that in prisons, the role of the medical officers often revolved around diagnosis and discipline rather than treatment and care. Indeed, by the 1870s, prison superintendents questioned whether those 
who 'created trouble were not better fitted by their acts for a criminal lunatic asylum than the discipline of a convict prison' (TNA CO111/391/111).

Incarceration and the prison regime also caused mental ill health, with prison surgeons diagnosing 'insanity' or 'madness' when inmates engaged in certain behaviours. These were wide-ranging and included the intention or act of suicide, loss of speech or hearing, disinterest in one's surroundings, verbal incoherence, general agitation or fear of others, low spirits, the ripping of clothes and blankets, poor memory, violence, quarrelling, and spitting (PP 1875 [1338]a; TNA CO111/551/230). Beyond the use of this terminology, precise evidence of such actions and characteristics is sparse and fragmentary. However, in one 1849 case, an unfamiliar cultural practice, the consumption of urine by an Indian prisoner (used therapeutically by some communities in South Asia), was described as 'mental delusion' (TNA CO111/268). Generally, throughout the colonial era, the British used a range of terms to define and describe mental illness in prisons: lunatic, crazy, weak minded, feeble intellect, derangement of mind, insane, unsound, and mentally deficient (BL C.S.F.351, TNA CO113/1/25).

Sometimes medical officers disagreed about whether prisoners were feigning mental ill health in order to gain advantage (PP 1867-68 [3961]; BL C.S.F. 351). However, the asylum would not accept inmates until they had been fully certified as 'insane'. Thus, throughout the colonial period, a high number of prisoners were referred to Georgetown prison for 'mental observation' (BL C.S.F.351, TNA CO111/750/2). Those found 'mentally deficient' or 'weak minded' but not certifiably insane (in ways that are not available to us in the archives) were retained within the prison system. In accordance with prison rules, they were required to labour under the guidance of a medical officer, but only the governor could order further punishments for offences against discipline (TNA CO111/554). The close proximity of these prisoners to the prisons general population was recognised as being demoralising to both (TNA CO111/750/2).

By the turn of the twentieth century, British Guiana was incorporated into global discussions on criminal insanity, that is to say the difference between insane people committing offences, and prisoners becoming insane during their incarceration. One view was that only those who became insane in prison could be effectively treated (Earle 1904). Whilst in Britain, the two groups were confined separately, in the colony they remained mixed together in New Amsterdam asylum's Annex. Following the construction of the 'criminal asylum' of Broadmoor in England in 1863, the New Amsterdam institution opened in 1886 and received 37 prisoners in the first 15 years. In rare glimpses into their experience and agency, we know that in 1888 one such prisoner set the facility on fire. In later years, two others were said to have openly boasted that they would repeat the act, having fooled administrators into classifying them as 'insane' (Earle 1904, 64). By the end of the century the management of mentally ill prisoners had become an everyday reality for medical officers, because they threatened the smooth governance of the prisons. Detailed concerns regarding the role of the prison system in exacerbating and producing metal health problems are revealed in the surgeon general's annual reports from 1897-8. These divided prisoners into three categories: class 1 encompassed persons tried and acquitted of an offence on the grounds of insanity; class 2, persons who became afflicted with insanity whilst undergoing sentence; and class 3 , those who could not be classed in either of the above. In the first year the return identified eleven prisoners who were 'afflicted with insanity' whilst undergoing their sentence. This figure steadily increased until it peaked in 1907-8. Additional categories were added in 1906-7 to encourage the early diagnosis of those accused of crime, in what was in effect an attempt to prevent prisons from becoming pseudo-asylums (B.L C.S.F.351). 
Despite the belief that 'mental weakness' existed in many cases prior to imprisonment, the adverse effects of the prison environment in creating mental health problems were acknowledged by British officials from the earliest years. Even in the 1830s, before jail expansion proper began, there were calls for limitations on 'unnecessary aggravation of the sufferings of imprisonment': poor air and lack of exercise, inadequate rations, and summary punishment (PP 1830-31 [334]). Good quality rations were viewed as a means to counter the depression caused by incarceration (PP 1875 [1338]c, 29). In early nineteenth-century Britain and North America, there were experiments in separate, solitary, and silent imprisonment as the best means of effecting punishment, reform, and rehabilitation (Rothman 1998). The cost of building cellular accommodation, and the hot and humid climate, meant that Guyana's prisons largely escaped such experimental penology. In any case, by the late 1840 s, separate confinement had been condemned as excessively severe and fallen out of favour (TNA CO111/246). Nonetheless, the fact of hyper-incarceration in the colony, noted above, meant that the mental health impact of jails must have reached wide. One particular issue was the jailing of Indigenous Guyanese (Amerindians). Henry Kirke, former Sheriff of Demerara, wrote at the end of the nineteenth century that they 'pined away' and died in the architecturally and socially unfamiliar environment of confinement (Kirke 1898, 158-9).

Jail regimes impacted not just on inmates, but on officers' mental health. As early as 1854, it was said that the isolation of HMPS Mazaruni gave rise to 'temptations' including problematic alcohol consumption (TNA CO111/302). By 1859 Governor P.E. Wodehouse lamented that two senior officers were dead from drink; and a third so addicted to alcohol that he was unlikely to remain at Mazaruni for much longer (TNA CO111/323). He added that even good soldiers employed as wardens in the settlement eventually began drinking, a view that was reiterated during subsequent years (TNA CO111/324; TNA CO111/328). As Director of Prisons J. Brumel noted later in 1875, incarceration caused terror to convicts, but had 'a depressing influence' on officers. The responsibilities of the officers, and the nature of their duties often led to prolonged and constant periods on duty, and this produced physical and mental exhaustion (TNA CO111/391/111). Personnel from wardens to superintendents suffered from resignation, broken health, and anxiety (PP 1875 [1338], 132-4; PP 1876 [C.1517]; NAG AB1/236). Families of prison officers also suffered as they often lived inside prison compounds. As late as 1934 Superintendent of Georgetown prison W.F Hodgson wrote of the 'depressing effect' that living inside the prison walls was having on his wife. He claimed that his 7-year-old daughter was so nervous since an unspecified 'incident' with an insane prisoner 'that it requires a lot of persuasion to get her to go to bed at nights' (TNA CO111/719/3).

The examples presented above highlight some of the historical origins and continuities of the challenges and issues of diagnosing and treating prisoners and prison officers with mental illness. During the British colonial period, enslavement, migration and incarceration intertwined to cause mental ill health. Although the colonial authorities were compelled to act, they allocated limited funds and provisions that were rarely more than basic. This meant that despite the building of asylum facilities dating from 1842, during the British colonial period prisons continued to confine the mentally ill. This included those who were sick prior to incarceration, as well as those who became ill in prison. Although attempts to improve the care of prisoners with mental health disorders emerged with the establishment of a special annex to the New Amsterdam asylum in 1883, in practice effective treatment remained limited. This was partly a question of capacity, and partly of resources. However, it was also a consequence of fundamental and irresolvable tensions between the effects of confinement and punishment 
in prison facilities and the maintenance of good health. This was also the case for prisons personnel. Indeed, isolation combined with prison duties, and in some cases accommodation inside prison compounds, had ill-effects on superintendents, wardens, and their families.

\section{References}

Anderson C., M. Ifill, E. Adams and K. Moss (2020), 'Guyana's Prisons: Colonial Histories of Post-Colonial Challenges', The Howard Journal of Crime and Justice, 59, 3: 335-49.

Arnold, D. (1994) The Colonial Prison: Power, Knowledge, and Penology in 19th-Century India. In D. Arnold and D. Hardiman, eds, Subaltern Studies VIII, New Delhi: Oxford University Press, 148-87.

British Library [BL], C.S.F.351, British Guiana, Inspector of Prisons Reports, 1889-1939.

Browne, R.M. (2017) Surviving Slavery in the British Caribbean, Philadelphia PA: University of Pennsylvania Press.

Burnard T. and K. Candlin (2018), Sir John Gladstone and the Debate over the Amelioration of Slavery in the British West Indies in the 1820s. Journal of British Studies 57, 4: 760-82.

Donald, J.S. (1876) Notes on Lunacy in British Guiana. Journal of Mental Sciences, 22, 97: 76-81.

Earle, P.M. (1904) The Criminal Insane and Insane Criminal, in A.T. Ozzard and C.P. Kennard, eds, The British Guiana Medical Annual, Georgetown: Baldwin and Co.: 61-4.

Gibson, M. (2011) Global Perspectives on the Birth of the Prison. American Historical Review 116, 4: 1040-63.

Glenn, J.M. (2008) Mixed Jurisdictions in the Commonwealth Caribbean: Mixing, Unmixing, Remixing. Journal of Comparative Law 3, 1: 53-76.

Gramaglia, L. (2013) Migration and Mental Illness in the British West Indies 1838-1900: The Cases of Trinidad and British Guiana, in Catherine Cox and Hilary Marland, eds, Migration, Health and Ethnicity in the Modern World, Basingstoke: Palgrave: 61-82.

Robert Grieve (1880) Insanity in British Guiana. Journal of Mental Sciences 26, 115: 370-4.

- (2010) The Asylum Journal: conducted by the medical superintendent of the public lunatic asylum for British Guiana, Volume 1 (1881-1882), introduction by L. Gramaglia, The Caribbean Press, 2010 (online).

Hall, C. Draper, N., McClelland, K. Donington and R. Lang (2014) Legacies of British Slaveownership: Colonial Slavery and the Formation of Victorian Britain, Cambridge: Cambridge University Press.

Kirke, H. (1888) Our Criminal Classes. Timehri: being The Journal of the Royal Agricultural and Commercial Society of British Guiana, new series 2, 1: 1-16.

- (1898) Twenty-Five Years in British Guiana, London, Sampson Low, Marston and Company. 
Law, W.F. (1888) Insanity in British Guiana, in E.D. Roland, ed., The Georgetown Hospital Reports for 1887, Demerara: Baldwin and Co.: 19-34.

Morris, N. and D.J. Rothman, eds (1998) The Oxford History of the Prison: The Practice of Punishment in Western Society, New York NY: Oxford University Press.

Moss, K. Anderson, C., Ifill, M. and E. Adams (2019), 'Guyana's Prison System, 1814-1966' https://leicester.figshare.com/articles/Historical_Overviews of Guyanas Prisons 1814$\underline{1966 / 11591337}$ (accessed 8 March 2020).

Mustakeem, Sowande M. (2016) Slavery at Sea: Terror, Sex, and Sickness in the Middle Passage, Champagne IL: University of Illinois Press.

National Archives of Guyana [NAG] AB1/236: Minutes of the Proceedings of the Court of Policy, 27 June 1874, enc. report of the committee appointed to investigate and report generally on the question of the removal of the penal settlement from its present site, 27 June 1874 [W.F. Haynes Smith, T.H. Mackey, Josias Booker, and Jas. W. Davson].

Paton, D. (2004) No Bond But the Law: Punishment, Race, and Gender in Jamaican State Formation, 1780-1870, Durham NC: Duke University Press.

L.M. Penson (1926), The Making of a Crown Colony: British Guiana, 1803-33, Transactions of the Royal Historical Society 9: 107-34.

Rodney, W. (1981) A History of the Guyanese Working People, 1881-1905, Baltimore MD: Johns Hopkins University Press.

Roopnarine, L. (2014) Resistance and Adaptation among Indentured Indian Labourers in British Guiana during Indentureship, in M.S. Hassankhan, B.V. Lal and D. Munro (eds) Resistance and Indian Indenture Experience, comparative Perspectives, New Delhi: Manohar Publishers: 157-82.

Rothman, D.J. (1998) Perfecting the Prison: United States, 1789-1865, in N. Morris and D. Rothman, eds, The Oxford History of the Prison: the practice of punishment in western society, Oxford: Oxford University Press, 100-16.

Smith, L. (2014) Insanity, Race and Colonialism: Managing Mental Disorder in the PostEmancipation British Caribbean 1838-1914, Basingstoke: Palgrave.

The Annual Miscellany, or Local Guide; for the year 1817 (1817), Georgetown: William Baker [Royal Gazette Office].

TNA [The National Archives]:

-CO111/54/2 11 May 1826: Regulations for the treadmill, 9 March 1826.

- CO111/67/31 26 June 1829: Governor Benjamin D’Urban to George Murray, secretary of state for war and the colonies, 26 June 1829, enc. regulations for the house of correction and workhouse, Article 15. 
- CO111/246 19 December 1847 no. 220: Henry Grey, secretary of state for war and the colonies, to Governor William Walker, 22 July 1848.

- CO111/268 17 September 1849 no 142: Governor Henry Barkly to Earl Grey, 17 September 1849, enc: The Queen v. Auchabar Ray, 31 July 1849.

- CO111/302 16 November 1854 no 88: William Walker and James E Roney, legislative commissioners of the penal settlement, to Governor Philip E. Wodehouse, 31 October 1854.

- CO111/323 22 March 1859 no. 21: Governor Philip E. Wodehouse to Edward BulwerLytton, secretary of state for the colonies 10 March 1859; 20 May 1859 no 44: Wodehouse to Lytton, 20 May 1859.

- CO111/324 23 December 1859 no. 123: Governor Philip E. Wodehouse to Henry PelhamClinton, secretary of state for the colonies, 23 December 1859.

- CO111/328 15 June 1860 no 84: William Walker, secretary to government and official commissioner of HMPS Mazuruni, to Governor Philip E. Wodehouse, 4 June 1860, enc. Chief Justice William Arrindell to Wodehouse, 5 June 1860.

- CO111/391/111 8 August 1872 no. 11: report on penal settlement at Massaruni: Governor John Scott to Henry Herbert, secretary of state for the colonies, enc. 1871 Annual Report and Annual Report of F.H Andrews, medical officer, 1 January 1872.

- CO111/551/230 Convict Makundi: Charles T. Cox, secretary to government British Guiana, to Victor Bruce, secretary of state for the colonies, 18 July 1906, enc. report on the case of Mokandi, 92773 ex 'Main', 1902, plantation 'Wales", Berbice, 17 April 1906.

- CO111/554/Home Office Convict Makundi: Ernley Blackwell, assistant secretary Home Office, to Winston Churchill, under secretary of state for the colonies, 4 September 1906.

- CO111/719/3 Confidential, 1934 prison report: inadequacy of present accommodation at Georgetown prison: Crawford Douglas-Jones, secretary to government British Guiana, to Philip Cunliffe-Lister, 12 July 1934, enc. Superintendent W.F. Hodgson, Georgetown Prison, to W.E.H. Bradburn, inspector of prisons, 10 May 1934.

- CO111/750/2 Confidential, 1937 prison report: Governor Wilfrid Edward Francis Jackson to Malcolm Macdonald, secretary of state for the colonies, 17 March 1939.

- CO113/ 1/16: An ordinance for the punishment of idle and disorderly persons, rogues, vagabonds, and other vagrants, 1838 .

- CO113/1/23: An ordinance to introduce into the colony of British Guiana the laws of England with respect to riots, routs, and unlawful and tumultuous assemblies, 1846.

- CO113/1/25: An ordinance for the safe custody of insane persons charged with offences, 1846 . 
- CO113/1/30: An ordinance for regulating the rights, duties and relations of employers and servants in the colony of British Guiana, 1846.

- CO113/2/20: An ordinance to provide general regulations for immigrants introduced into the colony of British Guiana, 1850.

- CO116/208-11, 213-21: Blue Books of Statistics: British Guiana, 1839-42, 1844-7.

- CO116/176-181: Blue Books of Statistics: Berbice, 1829-34.

UK Acts of Parliament:

- 1 \& 2 Vict., c. 14. Criminal Lunatics Act, 1838.

- 3 \& 4 Vict., c. 54. Criminal Lunatics Act, 1840.

- 8 \& 9 Vict., c. 100. Lunatics Act, 1845.

UK House of Commons Parliamentary Papers [PP]:

- 1826-7 [008] Papers in explanation of the measures adopted by His Majesty's government for the melioration of the condition of the slave population in His Majesty's possessions in the West Indies, and on the continent of South America, and at the Cape of Good Hope. In continuation of the papers presented in the year 1926. Part II. 1827. (Berbice. Trinidad. Cape of Good Hope): An Ordinance for promoting the Religious Instruction and bettering the State and Condition of the Slave Population in His Majesty's Colony of Berbice [Slave Code], 23 October 1826.

- 1830-31 [334] Gaols, West Indies. Copies of Correspondence relative to the State of the Gaols in the West Indies and the British Colonies in South America; and also, of any instructions which have been sent out from the Colonial Office relative to such Prisons, 30 March 1831: Extract from the Appendix to the Report of the Legal Commissioners, Commissioners Jabez Henry and Fortunatus Dwarris to Sir George Murray, secretary of state for war and the colonies, 4 June 1829.

- 1867-68 [3961] Prison Discipline in the Colonies. Digest and Summary of Information Respecting Prison in the Colonies, supplied by the Governors of Her Majesty's Colonial Possessions, in answer to Mr Secretary Cardwell's Circular Despatches of the $16^{\text {th }}$ and $17^{\text {th }}$ January 1865 (London: HM's Stationery Office, 1867): Governor Francis Hincks, British Guiana, to Buckingham and Chandos, secretary of state for the colonies, 7 December 1867.

- 1871 [393] Report of the commissioners appointed to enquire into the treatment of immigrants in British Guiana (London: Clowes and Son, 1871), Appendix G: Case of Three Immigrants, indentured to Plantation Good Success, Wakenaam. Complaint of ill-usage by the Manager, Mr. Finlay Matheson, 15 December 1869.

- 1875 [1338]a Papers Relating to the Improvement of Prison Discipline in the Colonies (London, Harrison and Sons, 1875): Report on the Penal Settlement at Massaruni for 1873, 24 February 1874, enc. W.S.B. Pollard, Surgeon HMPS Mazaruni, to Superintendent T. Sealy, 6 February 1874.

- 1875 [1338]b Papers Relating to the Improvement of Prison Discipline in the Colonies (London, Harrison and Sons, 1875): W.F. Haynes Smith, Attorney General, to W.A.G. Young, secretary to government, 28 November 1874. 
- 1875 [1338]c Papers Relating to the Improvement of Prison Discipline in the Colonies (London, Harrison and Sons, 1875): Report on the Penal Settlement at Massaruni for 1873, 24 February 1874.

- [C.1517] Further papers relating to the improvement of prison discipline in the colonies, Harrison and Sons, 1876: J. Brumell, Director of Prisons, to W.A.G. Young, Secretary to government, 1 March 1875. 